\title{
Hybrid system of nickel-cobalt hydroxide on carbonised natural cellulose materials for supercapacitors
}

\author{
Luyun Jiang $^{1}$ - Sophi Shanmuganathan ${ }^{1}$ - Geoffrey W. Nelson ${ }^{1} \cdot$ Seong Ok Han $^{2}$ • \\ Heeyeon $\mathrm{Kim}^{2}$ • I Na Sim ${ }^{2}$ John S. Foord ${ }^{1}$
}

Received: 2 February 2017 /Revised: 1 August 2017 / Accepted: 2 August 2017 /Published online: 14 September 2017

(C) The Author(s) 2017. This article is an open access publication

\begin{abstract}
Advanced carbon materials formed from abundant biomass are an exciting and promising class for energy devices due to the clear advantages of low cost, sustainability and good physical and electrochemical properties. However, these materials typically do not compete well with their metal functionalised counterparts. In this work, we demonstrate that $x \mathrm{Co}(\mathrm{OH})_{2}-(1-x) \mathrm{Ni}(\mathrm{OH})_{2}$ with various $\mathrm{Ni}$ Co ratios can be deposited onto biomass-derived carbon to make a hybrid inorganic-carbon electrode with tuneable physical features and electrochemical performance. These features were tuned by adjusting the Ni:Co ratio within precursor solutions. The electrodes had shown a capacitance ranging from 780.7 to $2041 \mathrm{~F} \mathrm{~g}^{-1}$, which is very close to the theoretical value for $\mathrm{Ni}(\mathrm{OH})_{2}\left(2365 \mathrm{~F} \mathrm{~g}^{-1}\right)$. A hypothesis is presented to help explain this performance for a modified, biomass-derived carbon electrode.
\end{abstract}

Keywords Supercapacitors $\cdot$ Natural cellulose $\cdot$ Nickelcobalt hydroxide, carbon

Electronic supplementary material The online version of this article (doi:10.1007/s10008-017-3723-z) contains supplementary material, which is available to authorized users.

Seong Ok Han

sohan@kier.re.kr

$\triangle$ John S. Foord

john.foord@chem.ox.ac.uk

1 Department of Chemistry, University of Oxford, South Parks Road, Oxford OX1 3TA, UK

2 Energy Materials Research Laboratory, Korea Institute of Energy Research, Daejeon 305-343, South Korea

\section{Introduction}

Sustainable and renewable energy sources like solar and wind are of strategic importance in modern society, due to the shortage of fossil fuels and increasing concern for the environment. However, the supply of these forms of energy is sporadic; therefore, it needs reliable energy storage devices to store the energy and release them when necessary. Electrical doublelayer capacitance (EDLC, also called supercapacitor) is a form of energy storage based on the electrochemical charge and discharge within the electric double layer at its interface. It has the advantages of having rapid charge and discharge, high specific power, long service life, and excellent cycle stability and can be designed to be environmentally friendly [1-3]. However, the energy density in EDLC is low, which limits its applications. To increase the energy density, pseudocapacitors of transition metal oxides or conductive polymers, such as $\mathrm{RuO}_{2}, \mathrm{Mn}_{3} \mathrm{O}_{4}, \mathrm{~V}_{2} \mathrm{O}_{5}$ and $\mathrm{NiCo}_{2} \mathrm{O}_{4}$, are introduced to build hybrid capacitors [3, 4]. For example, $\mathrm{RuO}_{2}$ is predicted to provide capacitance as high as $1580 \mathrm{~F} \mathrm{~g}^{-1}$ [5]. However, the high costs and the toxicity of many transition metal oxides limit their widespread use. Nickel hydroxide has attracted great interest in the past few years because of its low cost, non-toxicity and its high theoretical specific capacitances $\left(2365 \mathrm{~F} \mathrm{~g}^{-1}\right)$ [4, 6-12].

However, $\mathrm{Ni}(\mathrm{OH})_{2}$ suffers from slow ion diffusion rates and poor electrical conductivity. Two methods are commonly used to address these problems. One is the use of high electrical conductive substrates, for example graphene [13], $\mathrm{TiO}_{2}$ nanotubes [14], nickel foam [6] and carbon nanotube [15]. Conversion of abundant and renewable biomass materials also starts to play a role $[8,16]$. Another method is the substitution of nickel by other metals to enhance conductivity; cobalt is 
usually used because it shares a similar crystal structure with $\mathrm{Ni}$ [17]. The co-deposition of $\mathrm{Ni}$ and Co can reach a high supercapacitance of $1920 \mathrm{~F} \mathrm{~g}^{-1}$, consistently higher than the counterpart of $\mathrm{Ni}$ or Co modified alone [14, 17-21]. Intensive research has focussed on the structure of $\mathrm{Ni}-\mathrm{Co}$ compounds. Yang et al. [3] designed three-dimensional concentration-gradient Ni-Co hydroxide nanostructures, obtaining a specific capacitance of $1760 \mathrm{~F} \mathrm{~g} \mathrm{~g}^{-1}$; Xia et al. [12] reported a porous nano-Ni/Co $(\mathrm{OH})_{2}$ nanoflake composite film $\left(1920 \mathrm{~F} \mathrm{~g}^{-1}\right)$. $\mathrm{NiCo}_{2} \mathrm{O}_{4}$ nanowires were coated with nickel-cobalt hydroxide nanosheets $\left(1.64 \mathrm{~F} \mathrm{~cm}^{-2}\right)$. Doughnut-like $\mathrm{Ni}(\mathrm{OH})_{2}-$ $\mathrm{Co}(\mathrm{OH})_{2}$ composites were grown by $\mathrm{Li}$ et al. [22], with a capacitance of $2193 \mathrm{~F} \mathrm{~g}^{-1}$. Recently, Yu et al. [11] found a yolk-shelled Ni-Co mixed oxide nanoprisms with capacitance higher than $1000 \mathrm{~F} \mathrm{~g}^{-1}$. Due to the complex structures, many of the composites above require sophisticated techniques and multi-step processes.

Recently, we successfully converted natural cellulose materials, cotton pulp (CP), to a high conductive carbon nanofibre material by a simple two-stage thermal treatment [23]. This biomass-derived material is a good candidate for hybrid capacitors due to its large surface area, tailored pore size, high specific capacitance, excellent stability and good electrochemical properties. Our goal is to create a new generation of biomass-derived supercapacitors, with the advantages of higher energy densities, and the sustainable use of both natural and metallic resources. Here, we report that the electrodeposition of $\mathrm{Ni}-\mathrm{Co}$ hydroxide on $\mathrm{CP}$ leads to $x \mathrm{Co}(\mathrm{OH})_{2}-(1-x) \mathrm{Ni}(\mathrm{OH})_{2}$ decorated $\mathrm{CP}$ supercapacitors. Deposited $\mathrm{Ni}(\mathrm{OH})_{2}$ nanospheres were found to be resting on top of $\mathrm{Co}(\mathrm{OH})_{2}$ which had previously crystallised on $\mathrm{CP}$. The specific capacitance from the bi-metal hydroxide is as high as $2041 \mathrm{~F} \mathrm{~g}^{-1}$, close to the theoretical value of $2365 \mathrm{~F} \mathrm{~g}^{-1}$. The synthetic method was demonstrated to be highly reproducible, which is an important characteristic for large-scale production of supercapacitors.

\section{Experimental}

Potassium hydroxide ( $\mathrm{KOH}, \geq 99.0 \%$ ), nickel(II) nitrate hexahydrate $\left(\mathrm{Ni}\left(\mathrm{NO}_{3}\right)_{2} \bullet 6 \mathrm{H}_{2} \mathrm{O}, \geq 99.0 \%\right)$, cobalt(II) nitrate hexahydrate $\left(\mathrm{Co}\left(\mathrm{NO}_{3}\right)_{2} \cdot 6 \mathrm{H}_{2} \mathrm{O}, \geq 98.0 \%\right)$, sodium acetate and acetic acid were obtained from Sigma-Aldrich (A.C.S. reagent grade). All solutions and subsequent dilutions were prepared with Milli-Q water (>18 M $\Omega \mathrm{cm}$ ). Electrochemical measurements were performed at room temperature $\left(20 \pm 2{ }^{\circ} \mathrm{C}\right)$ with a $\mu$-AUTOLAB III potentiostat (Eco-Chemie, Netherlands), running GPES software (version 4.9). A three-electrode electrochemical cell was used comprising a working electrode, a $\mathrm{Ag} / \mathrm{AgCl}$ reference electrode, and a platinum wire counter electrode.
Cotton pulp was prepared by first heating this material at $600{ }^{\circ} \mathrm{C}$ for 30 min under an inert, $\mathrm{N}_{2}$ atmosphere. The material was then carbonised at $1000^{\circ} \mathrm{C}$ for $30 \mathrm{~min}$ with a ramping rate of $5^{\circ} \mathrm{C} \mathrm{min}^{-1}$ in the same atmosphere. The carbonised $\mathrm{CP}$ was cut into small square pieces of $0.7 \mathrm{~cm}$ diameter and directly used as a working electrode with a titanium plate as current collector. Cotton pulp was left to soak in distilled Milli-Q water for $24 \mathrm{~h}$ in order to wet the material and provide full accessibility for electrolyte uptake [24, 25]. The characterisation of $\mathrm{CP}$, including thermogravimetric curves, scanning electron microscope, conductive atomic force microscope and the Brunauer-Emmett-Teller result, was reported in a previous paper [23].

The hybrid inorganic-biomass electrode was made by electrodepositing nickel hydroxide and cobalt hydroxide onto $\mathrm{CP}$ at $-1 \mathrm{~V}$ for $600 \mathrm{~s}$ in a solution containing $10 \mathrm{mM} \mathrm{Ni}\left(\mathrm{NO}_{3}\right)_{2} /$ $\mathrm{Co}\left(\mathrm{NO}_{3}\right)_{2}$ and $0.1 \mathrm{M}$ acetate buffer ( $\left.\mathrm{pH} 4.3\right)$. After the deposition, $x \mathrm{Co}(\mathrm{OH})_{2}-(1-x) \mathrm{Ni}(\mathrm{OH})_{2}$ was formed and the value of $x$ reflects the initial ratio of Ni:Co in the source. The amount of deposited $\mathrm{Ni}(\mathrm{OH})_{2} / \mathrm{Co}(\mathrm{OH})_{2}$ is calculated from a deposition chronogram to be about $0.45 \pm 0.06 \mathrm{mg}$ ( 21 samples). This amount is independent of the Ni:Co ratio. For comparison, depositions were also carried out at $-0.7 \mathrm{~V}$ for $600 \mathrm{~s}$ and $-1.3 \mathrm{~V}$ for $600 \mathrm{~s}$, giving the loading amounts of $0.27 \pm 0.04$ and $0.65 \pm 0.2 \mathrm{mg}$. Since the deposition at $-0.7 \mathrm{~V}$ was low loading and it was not reproducible at $-1.3 \mathrm{~V}$, deposition at $-1 \mathrm{~V}$ for $600 \mathrm{~s}$ was applied as a standard procedure. The capacitance was calculated by cyclic voltammetry $(\mathrm{CV})$ and galvanostatic charge/discharge (GCD) methods in $5 \mathrm{M} \mathrm{KOH}$. The specific capacitance calculated from the $\mathrm{CV}$ is based on the following equation [26]:

$C_{\mathrm{v}}=\int_{E_{1}}^{E_{2}} i(E) d E / 2\left(E_{2}-E_{1}\right) m v$

where $C_{v}$ is the specific capacitance of an individual sample, $\int_{E_{1}}^{E_{2}} i(E) d E$ is the total voltammetric charge obtained by integration of positive and negative sweeps, $E_{1}$ and $E_{2}$ are the potential limits, $m$ is the mass and $v$ is the scan rate. The scan rate of $5 \mathrm{mV} \mathrm{s}^{-1}$ is used for all measurements of specific capacitance.

The specific capacitance calculated from the GCD is based on the following equation [27]:

$C_{\mathrm{m}}=\frac{C}{m}=\frac{I \times \Delta t}{\Delta V \times m}$

where the $I$ is the discharge current, $\Delta t$ is the discharge time, $\Delta V$ is the potential drop during the discharge process in the range of $V_{\max }$ and $1 / 2 V_{\max }$ and $m$ is the mass for the electrode materials.

The surface morphology of the deposited electrodes was investigated by scanning electron microscopy (SEM, JEOL 
Fig. 1 SEM images of $\mathrm{CP}$ carbonised at $1000{ }^{\circ} \mathrm{C}$ a without modification, b low loading of $\mathrm{Co}(\mathrm{OH})_{2}-\mathrm{CP}\left(2 \mathrm{mM} \mathrm{Co}\left(\mathrm{NO}_{3}\right)_{2}\right)$, c high loading of $\mathrm{Co}(\mathrm{OH})_{2}-\mathrm{CP}$ $\left(10 \mathrm{mM} \mathrm{Co}\left(\mathrm{NO}_{3}\right)_{2}\right)$ and $\mathbf{d}$ $\mathrm{Co}_{0.2}(\mathrm{OH})_{2}-\mathrm{Ni}_{0.8}(\mathrm{OH})_{2}-\mathrm{CP}$ $\left(2 \mathrm{mM} \mathrm{Co}\left(\mathrm{NO}_{3}\right)_{2}\right.$ and $8 \mathrm{mM}$ $\left.\mathrm{Ni}\left(\mathrm{NO}_{3}\right)_{2}\right)$
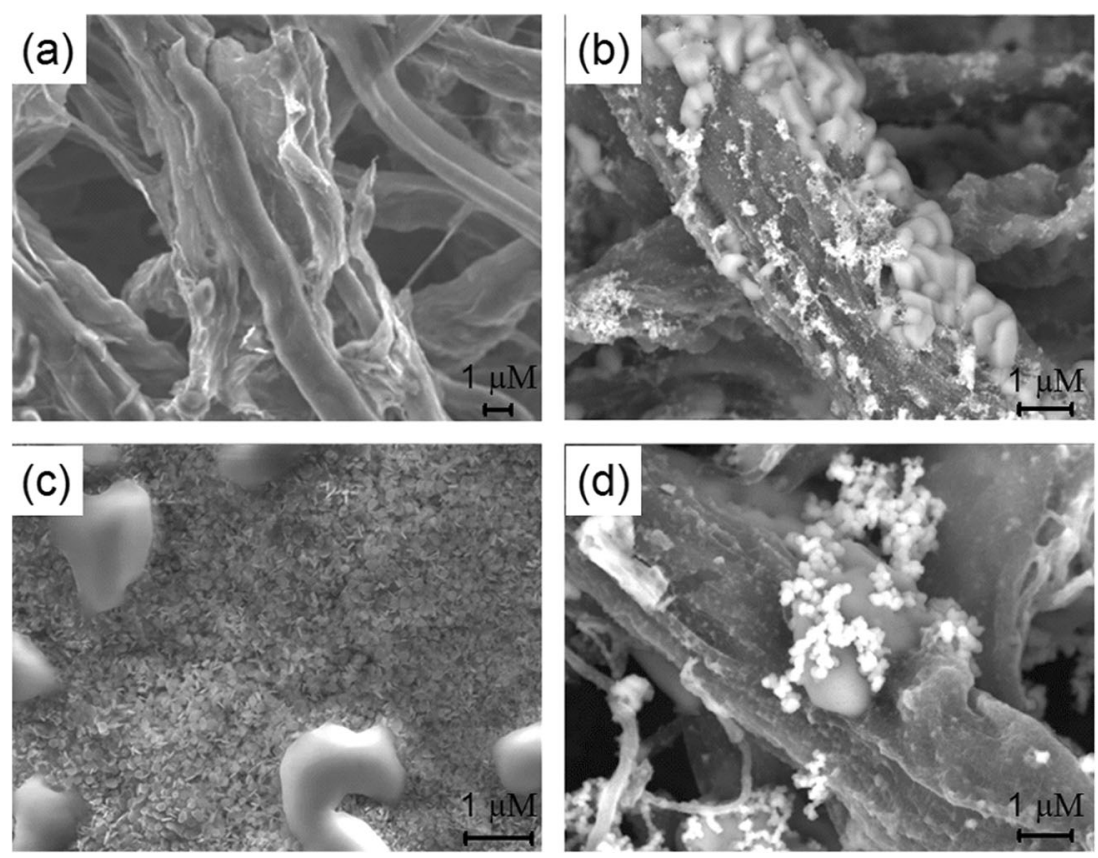

JSM-6500F). Surface chemistry was characterised using Xray photoelectron spectroscopy (XPS) using an Al-K $\alpha$ X-ray source at pressures of $10^{-8}-10^{-9}$ Torr. Spectra were analysed using CasaXPS software, with Shirley backgrounds and Wagner atomic sensitivity values [28]. X-ray diffraction (XRD) patterns were obtained from a Phillips X'pert PRO diffractometer operating at $30 \mathrm{~mA}$ and $40 \mathrm{kV}$. The samples were scanned in an angular range of $10^{\circ}$ to $80^{\circ}$.

\section{Results and discussion}

\section{Characterisation of $\mathrm{Ni}(\mathrm{OH})_{2}-\mathrm{CP}, \mathrm{Co}(\mathrm{OH})_{2}-\mathrm{CP}$ and $\mathrm{Co}_{x}(\mathrm{OH})_{2}-\mathrm{Ni}_{1-x}(\mathrm{OH})_{2}-\mathrm{CP}$}

The morphology of cotton pulp electrodes was evaluated using SEM, as shown in Fig. 1. Pure CP sample (Fig. 1a)

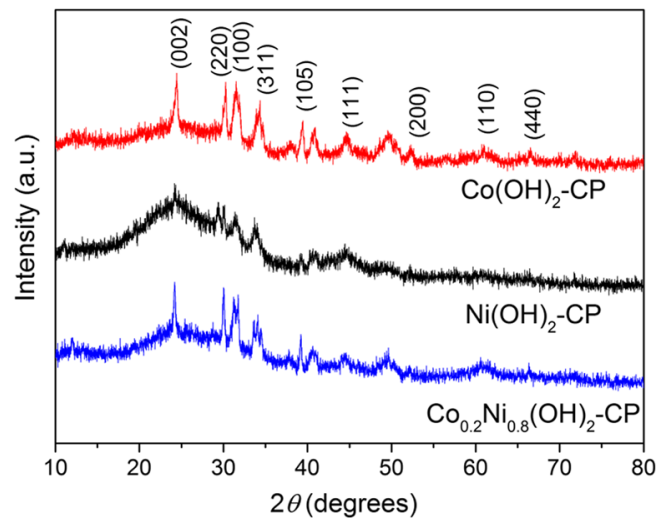

Fig. $2 \mathrm{XRD}$ spectrum of $\mathrm{Ni}(\mathrm{OH})_{2}-\mathrm{CP}, \mathrm{Co}(\mathrm{OH})_{2}-\mathrm{CP}$ and $0.2 \mathrm{Co}(\mathrm{OH})_{2}-$ $0.8 \mathrm{Ni}(\mathrm{OH})_{2}-\mathrm{CP}$ was made of smooth carbon fibre with diameter of about $3 \mu \mathrm{m}$. Figure $1 \mathrm{~b}$, c shows $\mathrm{Co}(\mathrm{OH})_{2}-\mathrm{CP}$ at low loading (deposited in a solution of $\left.2 \mathrm{mM}\left[\mathrm{Co}\left(\mathrm{NO}_{3}\right)_{2}\right]\right)$ and $\mathrm{Co}(\mathrm{OH})_{2}-\mathrm{CP}$ at high loading (deposited in solution of $10 \mathrm{mM}\left[\mathrm{Co}\left(\mathrm{NO}_{3}\right)_{2}\right]$ ), respectively. At low loadings of $\mathrm{Co}(\mathrm{OH})_{2}-\mathrm{CP}$, the carbon fibre was coated by crystallised $\mathrm{Co}(\mathrm{OH})_{2}$; at high loadings of $\mathrm{Co}(\mathrm{OH})_{2}-\mathrm{CP}$, the $\mathrm{CP}$ surface was totally covered by nanoplated $\mathrm{Co}(\mathrm{OH})_{2}$ and partially crystallised $\mathrm{Co}(\mathrm{OH})_{2}$. The co-deposited $0.2 \mathrm{Co}(\mathrm{OH})_{2}-0.8 \mathrm{Ni}(\mathrm{OH})_{2}-\mathrm{CP}$ is shown in Fig. $1 \mathrm{~d}$. It can be observed that homogeneous nanosphere-shaped $\mathrm{Ni}(\mathrm{OH})_{2}$ sits on the crystallised $\mathrm{Co}(\mathrm{OH})_{2}$ shell coating the carbon nanofibre. This structure is different from most other $\mathrm{Co}-\mathrm{Ni}$ co-deposited structures, as mentioned in the introduction.

To gain further information on the structure and composition of nickel- and cobalt-coated CPs, we employed XRD and XPS measurements with results shown in Figs. 2 and 3, respectively. The XRD peak labels correspond to the standard powder diffraction patterns of $\mathrm{Ni}(\mathrm{OH})_{2}$ (JCPDS card no.140117), $\mathrm{Co}(\mathrm{OH})_{2}$ (JCPDS card no.JCPDS74-1057) and other references [9, 19-21, 29]. The diffraction peaks of electrodeposited $\mathrm{Ni}(\mathrm{OH})_{2}$ are weak and broad, suggesting low crystallinity. The low peak intensity shows that the $\mathrm{Ni}(\mathrm{OH})_{2}$ obtained from the electrodeposition have mostly amorphous structure [30]. It is in agreement with the literature [20].

The chemical composition of $\mathrm{CP}$ carbonised at $1000{ }^{\circ} \mathrm{C}$ was confirmed using XPS, as shown in Fig. 3a. Two main peaks appear at 285.1 and $532.0 \mathrm{eV}$, representing $\mathrm{C}$ 1s and $\mathrm{O} 1 \mathrm{~s}$, respectively. As there is no significant photoelectron signal from other elements, one concludes that these surfaces have little contamination. This high purity is advantageous, as other known biomass-derived materials, such as coconut 
Fig. 3 XPS spectra of a CP carbonised at $1000^{\circ} \mathrm{C}, \mathbf{b}$ $\mathrm{Ni}(\mathrm{OH})_{2}-\mathrm{CP}, \mathbf{c ~} \mathrm{Co}(\mathrm{OH})_{2}-\mathrm{CP}$ and d $0.2 \mathrm{Co}(\mathrm{OH})_{2}-0.8 \mathrm{Ni}(\mathrm{OH})_{2}-\mathrm{CP}$
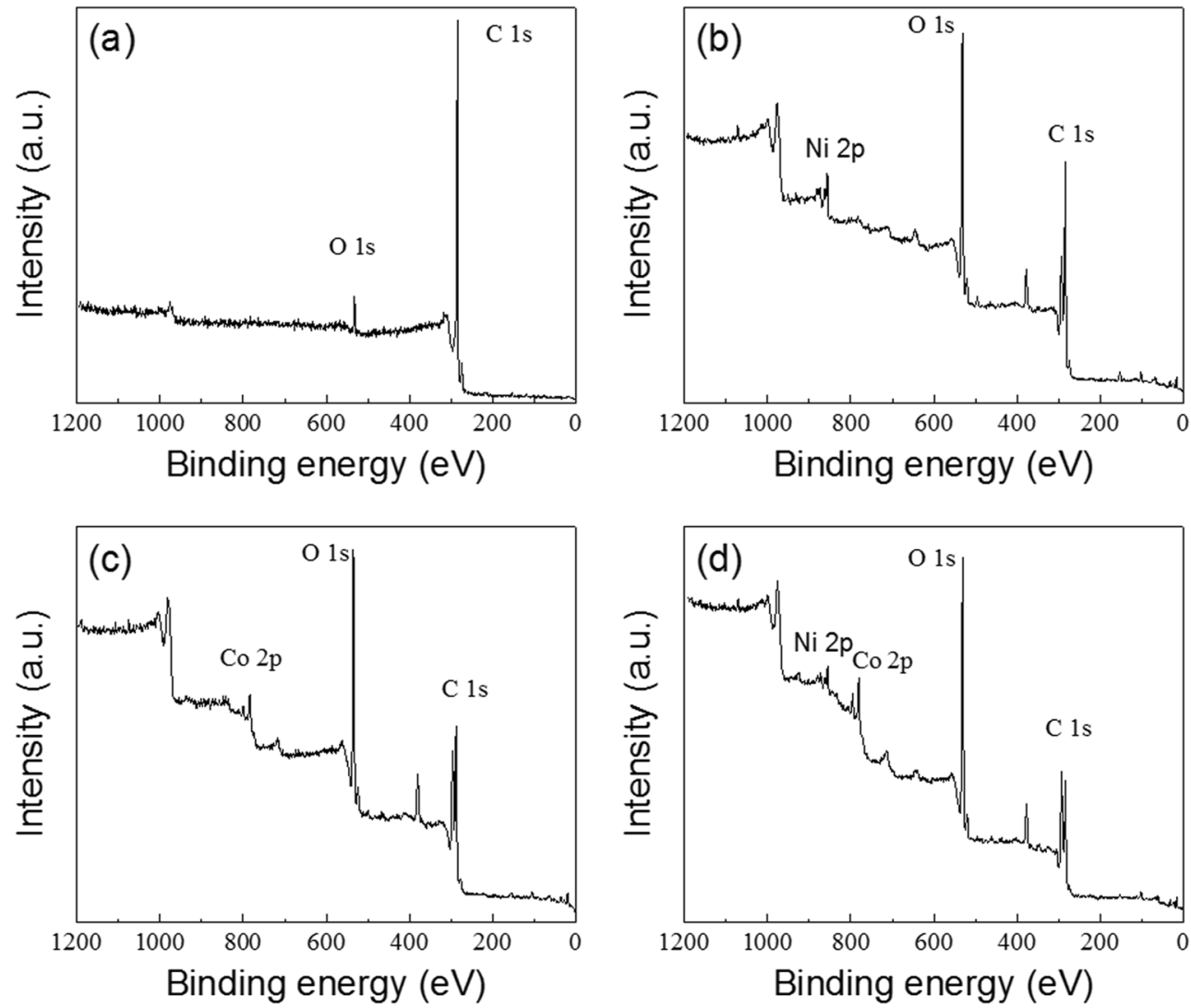

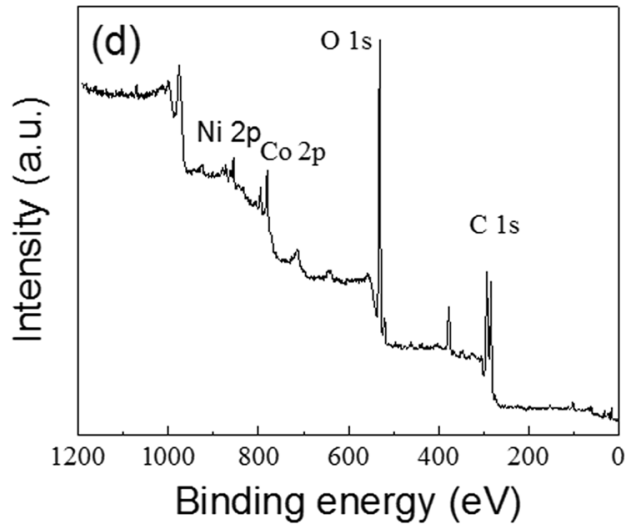

shells or rice husks, contain large amounts of impurities which are often difficult to remove $[31,32]$. By comparing the $\mathrm{C} 1 \mathrm{~s}$ and $\mathrm{O} 1 \mathrm{~s}$ XPS signal, we estimate that cotton pulp carbonised at $1000{ }^{\circ} \mathrm{C}$ comprises $81 \%$ carbon and $19 \%$ oxygen. The oxygen might be associated with oxygen functionalities exposed during the heat treatment or may have been adsorbed onto the surface due to environmental exposure in ambient conditions. Figure $3 \mathrm{~b}-\mathrm{d}$ shows the survey XPS spectra of $\mathrm{Ni}(\mathrm{OH})_{2}$ deposition, $\mathrm{Co}(\mathrm{OH})_{2}$ deposition and that for the codeposition of Ni-Co, respectively. The spectrum of $\mathrm{Co}(\mathrm{OH})_{2}-$ CP shows two Co 2p peaks at 780.96 and $796.32 \mathrm{eV}$ (see ESI Fig. 1a), corresponding to the Co $2 p_{3 / 2}$ and Co $2 p_{1 / 2}$ core levels. The difference in these peaks is $15.36 \mathrm{eV}$ which is the characteristic of the $\mathrm{Co}(\mathrm{OH})_{2}$ phase. Similarly, the binding energy difference between $\mathrm{Ni} 2 \mathrm{p}_{3 / 2}$ and $\mathrm{Ni} 2 \mathrm{p}_{1 / 2}$ is $\approx 17.74 \mathrm{eV}$

Table 1 XPS analysis of $\mathrm{Co}$ and $\mathrm{Ni}$ in $x \mathrm{Co}(\mathrm{OH})_{2}-(1-x) \mathrm{Ni}(\mathrm{OH})_{2}$ in various concentration ratios of $\mathrm{Co}\left(\mathrm{NO}_{3}\right)_{2}$ and $\mathrm{Ni}\left(\mathrm{NO}_{3}\right)_{2}$

\begin{tabular}{llll}
\hline$\left[\mathrm{Co}^{2+}\right]:\left[\mathrm{Ni}^{2+}\right]$ & Co (at.\%) & Ni (at.\%) & $x$ in $\mathrm{Co}_{x} \mathrm{Ni}_{1-x}(\mathrm{OH})_{2}$ \\
\hline $1: 4$ & 1.28 & 5.10 & 0.25 \\
$2: 3$ & 2.58 & 3.51 & 0.42 \\
$1: 1$ & 2.91 & 3.00 & 0.50 \\
$3: 2$ & 2.12 & 1.70 & 0.55 \\
$4: 1$ & 9.29 & 1.00 & 0.90 \\
\hline
\end{tabular}

(see ESI Fig. 1b), indicating the presence of a $\mathrm{Ni}(\mathrm{OH})_{2}$ phase. The peak positions of nickel and cobalt hydroxide in the composite material, in Fig. 1d, are very similar to the single components found in Fig. 1b, c. This result is in agreement with the aforementioned SEM images that two hydroxide particles grow separately: $\mathrm{Co}(\mathrm{OH})_{2}$ crystallising along the carbon nanofibre with $\mathrm{Ni}(\mathrm{OH})_{2}$ forming nanopheres on the top of $\mathrm{Co}(\mathrm{OH})_{2}$. Although some $\mathrm{Cl}$ and $\mathrm{K}$ signal arises due to the use of potassium chloride buffers, the contamination does not affect the above conclusions.

The concentration ratio of $\mathrm{Co}^{2+}$ and $\mathrm{Ni}^{2+}$ in the precursor electrolyte does not infer the actual surface composition in the final composite material. Therefore, it is necessary to determine the atomic percentages (at.\%) of cobalt and nickel in these $\mathrm{Co}-\mathrm{Ni}$ hydroxides using XPS. By factoring in the Wagner atomic sensitivity factors [33] for $\mathrm{C}(0.25), \mathrm{O}$ (0.66), Ni (3) and Co (2.5) for the primary photoelectron signal, the surface composition can be calculated. These results are shown in Table 1. This table compares the Co:Ni ratio of precursor electrolyte with the atomic percentage composition of $\mathrm{C}$ and Ni determined by XPS; the latter is used to determine a stoichiometric $x$ value in $x \mathrm{Co}(\mathrm{OH})_{2}-(1-$ $x) \mathrm{Ni}(\mathrm{OH})_{2}$. The actual surface composition of each sample shares a similar trend to $\left[\mathrm{Co}^{2+}\right]:\left[\mathrm{Ni}^{2+}\right]$, thereby indicating that material composition can be controlled by simple adjustment of the electrolyte concentration. 
Fig. $4 \mathrm{CV}$ of a $\mathrm{Ni}(\mathrm{OH})_{2}-\mathrm{CP}$ and raw $\mathrm{CP} ; \mathbf{b} \mathrm{Co}(\mathrm{OH})_{2}-\mathrm{CP}$ and raw $\mathrm{CP} ; \mathbf{c} 0.2 \mathrm{Co}(\mathrm{OH})_{2}-0.8 \mathrm{Ni}(\mathrm{OH})_{2}$, $0.5 \mathrm{Co}(\mathrm{OH})_{2}-0.5 \mathrm{Ni}(\mathrm{OH})_{2}$ and $0.8 \mathrm{Co}(\mathrm{OH})_{2}-0.2 \mathrm{Ni}(\mathrm{OH})_{2}$ in $1 \mathrm{M}$ $\mathrm{KOH}$ at $5 \mathrm{mV} / \mathrm{s}$; and $\mathbf{d}$ specific capacitance and oxidation peak potential as a function of $\mathrm{Co}: \mathrm{Ni}$ ratio
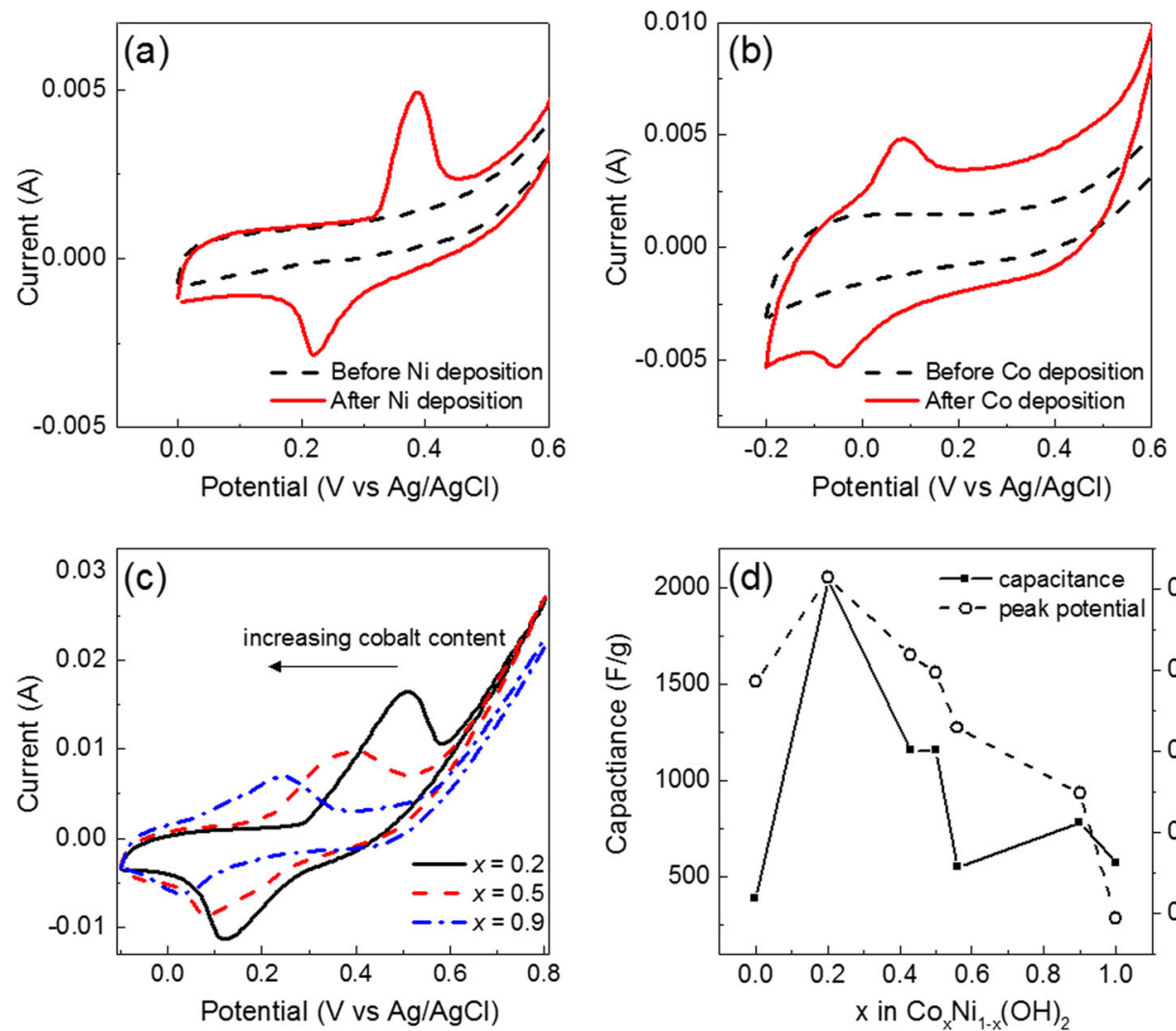

\section{Electrochemical measurements}

The supercapacitance was determined in $1 \mathrm{M} \mathrm{KOH}$ by cyclic voltammetry. The CV curves of $\mathrm{CP}$ before and after the deposition of $\mathrm{Ni}(\mathrm{OH})_{2}$ and $\mathrm{Co}(\mathrm{OH})_{2}$ are shown in Fig. $4 \mathrm{a}$, b, respectively. The expected redox peaks for each are observed after deposition. Each of the individual redox signals is well separated from each other. These redox peaks correspond to the following faradaic redox reactions:

$\mathrm{Ni}(\mathrm{OH})_{2}+\mathrm{OH} \rightleftharpoons \mathrm{NiOOH}+\mathrm{H}_{2} \mathrm{O}+\mathrm{e}$

$\mathrm{Co}(\mathrm{OH})_{2}+\mathrm{OH} \rightleftharpoons \mathrm{CoOOH}+\mathrm{H}_{2} \mathrm{O}+\mathrm{e}$

Table 2 Summary of peak potentials at $x \mathrm{Co}(\mathrm{OH})_{2}-(1-x) \mathrm{Ni}(\mathrm{OH})_{2}-\mathrm{CP}$ and the specific capacitance contribution to the deposited metal hydroxide

\begin{tabular}{lll}
\hline$x$ & Capacitance $(\mathrm{F} / \mathrm{g})$ & Peak potential $(\mathrm{V})$ \\
\hline 0 & 387.6 & 0.386 \\
0.2 & 2041.7 & 0.514 \\
0.43 & 1151.2 & 0.419 \\
0.5 & 1154.0 & 0.397 \\
0.56 & 548.4 & 0.329 \\
0.9 & 780.7 & 0.248 \\
1 & 570.5 & 0.094 \\
\hline
\end{tabular}

Different concentrations of cobalt nitrate and nickel nitrate were used to synthesise $x \mathrm{Co}(\mathrm{OH})_{2}-(1-x) \mathrm{Ni}(\mathrm{OH})_{2}$ and lead to different Ni:Co ratios in the co-deposited materials, as mentioned earlier. The redox behaviour of CP modified with $x \mathrm{Co}(\mathrm{OH})_{2}-(1-x) \mathrm{Ni}(\mathrm{OH})_{2}$ having differing values of $x(x=0$, $0.2,0.42,0.50,0.55,0.9$ and 1) was investigated. Representative cyclic voltammograms corresponding to $x=0.2,0.5$ and 0.9 are depicted in Fig. 4c. Although both $\mathrm{Ni}(\mathrm{OH})_{2}$ and $\mathrm{Co}(\mathrm{OH})_{2}$ are present, only one pair of redox peaks are observed. The absence of well-separated redox peaks implies that a synergetic compound has been obtained. These co-deposited electrodes have larger peak currents and peak areas than the electrodes modified by $\mathrm{Ni}(\mathrm{OH})_{2}$ or $\mathrm{Co}(\mathrm{OH})_{2}$ alone. This suggests that the $\mathrm{Co}(\mathrm{OH})_{2}$ shell-on-CP architecture with $\mathrm{Ni}(\mathrm{OH})_{2}$ nanoparticles is a favourable one. It is because $\mathrm{Co}(\mathrm{OH})_{2}$ provides a good support for the $\mathrm{Ni}(\mathrm{OH})_{2}$ nanoparticles and it increases the electron transfer between $\mathrm{Ni}(\mathrm{OH})_{2}$ and the $\mathrm{CP}$ nanofibre.

From the data in Fig. 4c, it is clear that the redox wave moves to even lower overpotentials as the Co content increases. This can be attributed to the redox potential of $\mathrm{Co}(\mathrm{OH})_{2}$ to $\mathrm{CoOOH}$ transition being more negative than that of $\mathrm{Ni}(\mathrm{OH})_{2}$ to $\mathrm{NiOOH}$. It is consistent with the idea that $\mathrm{Co}(\mathrm{OH})_{2}$ platelet growth would dominate at higher Co loading levels. A useful consequence of this observation is that the electrochemical behaviour of this synergetic material can be controlled by the $\left[\mathrm{Co}^{2+}\right]:\left[\mathrm{Ni}^{2+}\right]$ ratio in the electrolyte. 
Table 2 shows the shift of peak potentials and specific capacitances were plotted as a function of $x$ in $x \mathrm{Co}(\mathrm{OH})_{2}-(1-x) \mathrm{Ni}(\mathrm{OH})_{2}$ in Fig. 4 d. The specific capacitance purely attributed to the $\mathrm{Ni}-\mathrm{Co}$ hydroxide and the capacitance from CP was subtracted. The highest capacitance value, $2041.7 \mathrm{~F} \mathrm{~g}^{-1}$, was obtained when $x=0.2(1: 4$ cobalt:nickel ratio). This value is higher than twice as that obtained at $\mathrm{Co}(\mathrm{OH})_{2}-\mathrm{CP}\left(387.6 \mathrm{~F} \mathrm{~g}^{-1}\right)$ and triple than $\mathrm{Ni}(\mathrm{OH})_{2}-\mathrm{CP}\left(570.5 \mathrm{~F} \mathrm{~g}^{-1}\right)$. In general, a higher percentage of nickel than cobalt in the composite favoured the rise in capacitance. It is most likely that the cobalt substitution improves charging efficiency, resulting from the special structure of co-deposited materials. The rise in capacitance with increasing amounts of nickel is not unexpected $[18,20]$. Here, one hypothesis is proposed: The highly conductive $\mathrm{Co}(\mathrm{OH})_{2}$ shell provides a good support for the low-conductive $\mathrm{Ni}(\mathrm{OH})_{2}$ spheres and allows more $\mathrm{Ni}(\mathrm{OH})_{2}$ spheres to react. With the increased loading of [Co], nanoplate formation of $\mathrm{Co}(\mathrm{OH})_{2}$ is promoted; this material blocks the CP surface, as shown in the SEM image (Fig. 1c). Therefore, the specific capacitance decreases due to a lack of accessible electrochemical surface sites. Simultaneously, less $\mathrm{Ni}(\mathrm{OH})_{2}$ was present. Because $\mathrm{Ni}(\mathrm{OH})_{2}$ is the main contribution to the specific capacitance in Ni-Co composite [3], the specific capacitance drops.

\section{Conclusion}

In this work, a green and sustainable biomass-derived supercapacitor of nickel-cobalt hydroxide was obtained, giving a high specific supercapacitance close to the theoretical value of nickel hydroxide. Nickel-cobalt hydroxide was co-electrodeposited onto the carbonised cotton pulp materials, to build a hybrid supercapacitor derived from inorganic biomass. The SEM images showed that $\mathrm{Co}(\mathrm{OH})_{2}$ formed a crystallised shell around the microfibres of carbonised cotton pulp, on top of which nanosized $\mathrm{Ni}(\mathrm{OH})_{2}$ spheres sit. This special structure enhanced the specific capacitance to $2041.7 \mathrm{~F} \mathrm{~g}^{-1}$ at $\mathrm{Co}: \mathrm{Ni}$ ratio of 1:4. A likely explanation is that the electron transfer between nickel hydroxide and biomass carbon substrate is much faster in the presence of $\mathrm{Co}(\mathrm{OH})_{2}$.

Acknowledgements The authors are grateful for the financial support from the International Collaborative Energy Technology R\&D program of the Korea Institute of Energy Technology Evaluation and Planning (KETEP) grated financial resource from the Ministry of Trade, Industry and Energy, Republic of Korea (No. NP2014-0001 20138510040050). GWN acknowledges the financial support of a Corpus Christi College (Oxford) Research Grant.

Open Access This article is distributed under the terms of the Creative Commons Attribution 4.0 International License (http:// creativecommons.org/licenses/by/4.0/), which permits unrestricted use, distribution, and reproduction in any medium, provided you give appropriate credit to the original author(s) and the source, provide a link to the Creative Commons license, and indicate if changes were made.

\section{References}

1. Simon P, Gogotsi Y (2008) Materials for electrochemical capacitors. Nat Mater 7(11):845-854

2. Long C, Zheng M, Xiao Y, Lei B, Dong H, Zhang H, Hu H, Liu Y (2015) Amorphous Ni-Co binary oxide with hierarchical porous structure for electrochemical capacitors. ACS Appl Mater Interfaces 7(44):24419-24429. doi:10.1021/acsami.5b03036

3. Yang M, Cheng H, Gu Y, Sun Z, Hu J, Cao L, Lv F, Li M, Wang W, Wang Z, Wu S, Liu H, Lu Z (2015) Facile electrodeposition of 3D concentration-gradient $\mathrm{Ni}$-Co hydroxide nanostructures on nickel foam as high performance electrodes for asymmetric supercapacitors. Nano Res 8(8):2744-2754. doi:10.1007/s12274015-0781-3

4. Zhang Y-Z, Wang Y, Cheng T, Lai W-Y, Pang H, Huang W (2015) Flexible supercapacitors based on paper substrates: a new paradigm for low-cost energy storage. Chem Soc Rev 44:5181-5199

5. Hu C-C, Chang K-H, Lin M-C, Wu Y-T (2006) Design and tailoring of the nanotubular arrayed architecture of hydrous $\mathrm{RuO}_{2}$ for next generation supercapacitors. Nano Lett 6(12):2690-2695

6. Yang G-W, Xu C-L, Li H-L (2008) Electrodeposited nickel hydroxide on nickel foam with ultrahigh capacitance. Chem Commun 48: 6537-6539

7. Wang Y-M, Zhao D-D, Zhao Y-Q, Xu C-L, Li H-L (2012) Effect of electrodeposition temperature on the electrochemical performance of a Ni (OH) 2 electrode. RSC Adv 2(3):1074-1082

8. Huang L, Chen D, Ding Y, Feng S, Wang ZL, Liu M (2013) Nickel-cobalt hydroxide nanosheets coated on $\mathrm{NiCo}_{2} \mathrm{O}_{4}$ nanowires grown on carbon fiber paper for high-performance pseudocapacitors. Nano Lett 13(7):3135-3139

9. Wang H, Holt CM, Li Z, Tan X, Amirkhiz BS, Xu Z, Olsen BC, Stephenson T, Mitlin D (2012) Graphene-nickel cobaltite nanocomposite asymmetrical supercapacitor with commercial level mass loading. Nano Res 5(9):605-617

10. Sook-Keng C, Zainal Z, Kar-Ban T, Yusof NA, Daud Wan Yusoff WM, Prabaharan SRS (2015) Synthesis and electrochemical properties of nanostructured nickel-cobalt oxides as supercapacitor electrodes in aqueous media. Int J Energy Res 39(10):1366-1377. doi: 10.1002/er.3339

11. Yu L, Guan B, Xiao W, Lou XWD (2015) Formation of yolkshelled Ni-Co mixed oxide nanoprisms with enhanced electrochemical performance for hybrid supercapacitors and lithium ion batteries. Adv Energy Mater 5(21). doi:10.1002/aenm.201500981

12. Li M, Cheng JP, Liu F, Zhang XB (2015) In situ growth of nickelcobalt oxyhydroxide/oxide on carbon nanotubes for high performance supercapacitors. Electrochim Acta 178:439-446. doi:10. 1016/j.electacta.2015.08.041

13. Xu Y, Huang X, Lin Z, Zhong X, Huang Y, Duan X (2013) Onestep strategy to graphene/ $\mathrm{Ni}(\mathrm{OH})_{2}$ composite hydrogels as advanced three-dimensional supercapacitor electrode materials. Nano Res 6(1):65-76

14. Yang F, Yao J, Liu F, He H, Zhou M, Xiao P, Zhang Y (2013) NiCo oxides nanowire arrays grown on ordered $\mathrm{TiO}_{2}$ nanotubes with high performance in supercapacitors. J Mater Chem A 1(3):594601

15. Frackowiak E, Metenier K, Bertagna V, Beguin F (2000) Supercapacitor electrodes from multiwalled carbon nanotubes. Appl Phys Lett 77(15):2421-2423 
16. Yu Z-Y, Chen L-F, Yu S-H (2014) Growth of $\mathrm{NiFe}_{2} \mathrm{O}_{4}$ nanoparticles on carbon cloth for high performance flexible supercapacitors. $\mathrm{J}$ Mater Chem A 2(28):10889-10894

17. Wei T-Y, Chen C-H, Chien H-C, Lu S-Y, Hu C-C (2010) A costeffective supercapacitor material of ultrahigh specific capacitances: spinel nickel cobaltite aerogels from an epoxide-driven sol-gel process. Adv Mater 22(3):347

18. Gupta V, Gupta S, Miura N (2008) Potentiostatically deposited nanostructured $\mathrm{Co}_{\mathrm{x}} \mathrm{Ni}_{(1-\mathrm{x})}$ layered double hydroxides as electrode materials for redox-supercapacitors. J Power Sources 175(1):680-685

19. Yuan C, Li J, Hou L, Zhang X, Shen L, Lou XWD (2012) Ultrathin mesoporous $\mathrm{NiCo}_{2} \mathrm{O}_{4}$ nanosheets supported on $\mathrm{Ni}$ foam as advanced electrodes for supercapacitors. Adv Funct Mater 22(21): 4592-4597

20. Hu Z-A, Xie Y-L, Wang Y-X, Wu H-Y, Yang Y-Y, Zhang Z-Y (2009) Synthesis and electrochemical characterization of mesoporous $\mathrm{Co}_{\mathrm{x}} \mathrm{Ni}_{(1-\mathrm{x})}$ layered double hydroxides as electrode materials for supercapacitors. Electrochim Acta 54(10):2737-2741

21. Xia X, Tu J, Zhang Y, Mai Y, Wang X, Gu C, Zhao X (2011) Threedimentional porous nano- $\mathrm{Ni} / \mathrm{Co}(\mathrm{OH})_{2}$ nanoflake composite film: a pseudocapacitive material with superior performance. J Phys Chem C 115(45):22662-22668

22. Li J, Yang M, Wei J, Zhou Z (2012) Preparation and electrochemical performances of doughnut-like $\mathrm{Ni}(\mathrm{OH})_{2}-\mathrm{Co}(\mathrm{OH})_{2}$ composites as pseudocapacitor materials. Nano 4(15):4498-4503

23. Jiang L, Nelson GW, Han SO, Kim H, Sim I, Foord JS (2015) Natural cellulose materials for supercapacitors. Electrochim Acta 192:251-258
24. Gui Z, Zhu H, Gillette E, Han X, Rubloff GW, Hu L, Lee SB (2013) Natural cellulose fiber as substrate for supercapacitor. ACS Nano 7(7):6037-6046

25. Li T-Q, Henriksson U, Klason T, Ödberg L (1992) Water diffusion in wood pulp cellulose fibers studied by means of the pulsed gradient spin-echo method. J Colloid Interface Sci 154(2):305-315

26. Chen W, Fan Z, Gu L, Bao X, Wang C (2010) Enhanced capacitance of manganese oxide via confinement inside carbon nanotubes. Chem Commun 46(22):3905-3907

27. Liu M-C, Kong L-B, Zhang P, Luo Y-C, Kang L (2012) Porous wood carbon monolith for high-performance supercapacitors. Electrochim Acta 60:443-448

28. Michigan State University, Department of Chemistry. http://www. cem.msu.edu/ cem924sg/XPSASFs.html. http://www.cem.msu. edu/ cem $924 \mathrm{sg} /$ XPSASFs.html

29. Barnard R, Crickmore G, Lee J, Tye F (1980) The cause of residual capacity in nickel oxyhydroxide electrodes. J Appl Electrochem 10(1):61-70

30. Hamdan MS, Othman MR (2013) Preparation and characterization of nano size $\mathrm{NiOOH}$ by direct electrochemical oxidation of nickel plate. Int J Electrochem Sci 8(4):4747-4760

31. Mi J, Wang X-R, Fan R-J, Qu W-H, Li W-C (2012) Coconut-shellbased porous carbons with a tunable micro/mesopore ratio for highperformance supercapacitors. Energy Fuel 26(8):5321-5329

32. Sevilla M, Fuertes AB (2009) The production of carbon materials by hydrothermal carbonization of cellulose. Carbon 47(9):22812289

33. Briggs D, Seah MP (1990) Practical surface analysis. Volume 1. Auger and X-ray Photoelectron spectroscopy. John Wiley and Sons, Chichester 